\title{
INDONESIA AND THE INTERNATIONAL REFUGEE CRISIS: The Politics of Refugee Protection
}

\author{
R.A. Rizka Fiani Prabaningtyas \\ Centre for Political Studies \\ Indonesian Institute of Sciences (LIPI), Jakarta, Indonesia \\ Email:Prabaningtyas.rizka@gmail.com
}

\begin{abstract}
This article examines the politics of international refugee protection in Indonesia's domestic contexts to better understand the discourse of security and protection within the context of Indonesia's policies and practices in handling refugees This understanding is crucial to find insights relating to the protection gap in the Asia-Pacific region, as Indonesia holds a salient position in advancing the refugee protection regime in the region. Although Indonesia does not seem to employ a specific restrictive asylum and immigration policy as a filtering mechanism to prevent refugee flows from entering their territory, its anxiety and ambivalence to accommodate requests for protection from asylum seekers have characterized its approach towards refugee crises over time. Specifically, this essay analyzed the political discourse and practices in a specific social and political context by historically tracing the experiences of Indonesia in dealing with three refugee crises that took place in the region, namely the Indochinese refugee crisis, the Tampa incident, and the Rohingya humanitarian crisis. It will be argued that the contested discourse and practices of protection in the midst of continuing modulation of insecurity within states are the constitutive factor for the production of state's approaches to protect refugees. This potentially affected the way states conduct their domestic and foreign policies in the attempt to affirm their national stance towards global refugee phenomena and to avoid greater responsibility without guaranteed cooperative behaviors and solidarity from other counterparts.
\end{abstract}

Keywords: Indonesia, refugee policy, protection, securitization, refugee crisis

\begin{abstract}
Abstrak
Artikel ini membahas politik perlindungan pengungsi internasional dalam konteks domestik Indonesia untuk lebih memahami wacana keamanan dan perlindungan dalam konteks kebijakan dan praktik Indonesia dalam menangani pengungsi. Pemahaman ini sangat penting untuk menemukan jawaban dari besarnya kesenjangan perlindungan untuk pengungsi di wilayah Asia-Pasifik. Indonesia memegang posisi penting dalam meningkatkan fungsi dari rezim perlindungan pengungsi di kawasan tersebut. Meskipun Indonesia tampaknya tidak memiliki kebijakan imigrasi khusus yang restriktif sebagai mekanisme penyaringan untuk mencegah aliran pengungsi memasuki wilayah teritorialnya, ambivalensi dan kegamangan dalam mengakomodasi permintaan perlindungan dari para pencari suaka merefleksikan garis besar pendekatannya terhadap krisis pengungsi dari waktu ke waktu. Secara khusus, esai ini menganalisis wacana dan praktik-praktik politik dalam konteks dinamika sosiopolitik dalam negeri melalui analisis pengalaman historis Indonesia dalam menghadapi tiga krisis pengungsi yang terjadi di kawasan
\end{abstract}


Asia-Pasifik, yaitu krisis pengungsi Indochina, insiden Tampa, dan krisis pengungsi Rohingya. Argumen utama dalam tulisan ini adalah wacana yang diperdebatkan dan praktik-praktik perlindungan terhadap pengungsi di tengah modulasi rasa tidak aman di dalam negara adalah faktor utama bagi terciptanya pendekatan negara dalam memaknai pemberian perlindungan terhadap pengungsi luar negeri. Pendekatan ini mempengaruhi cara negara merumuskan dan menjalankan kebijakan domestik dan luar negeri untuk menegaskan sikap nasionalnya terhadap fenomena pengungsi global dan untuk menghindari tanggung jawab yang lebih besar tanpa jaminan kerja sama dan solidaritas dari negara lainnya.

Kata kunci: Indonesia, kebijakan pengungsi, perlindungan, sekuritisasi, krisis pengungsi

\section{INTRODUCTION}

In the Asia-Pacific region, providing protection for 8.3 million displaced people has been a significant concern for international humanitarian organizations and affected states. Although most states acknowledge that the growing refugee population is a shared global challenge, the various practices of restrictive asylum policies and closed-border approaches undermine the mandate of the international refugee regime to ensure international protection for people fleeing persecution. Many scholarly works have attempted to unpack the deficit of protection in responding to massive human displacements in the Asia-Pacific region. Historical observations of the Indochinese refugee crisis in the I970s provide empirical evidence of how the region dealt with a large-scale humanitarian tragedy in Southeast Asia through coordinated international responses (Chantavanich \& Reynolds, I988).

In reference to refugee protection in the Southeast Asia region, Some (Barcher, I992; Moretti, 20I8) argue that Southeast Asian countries deliver protections for the refugee populations to a certain degree despite the reluctance of most states in the region to ratify the 195I Refugee Convention. However, Barcher (1992) argues that the existing protection practices were built upon a fragile and limited political commitment to humanitarian and non-refoulment principles because most Southeast Asian countries have used the issue of asylum seekers as a political instrument in regional power struggles. Besides, other scholars have examined the experiences of Asia-Pacific countries in offering permanent asylum, such as Australia, China and Japan, to demonstrate that while some of these countries maintain a quota for refugee resettlements, they are now increasingly hesitant (if not reluctant) and selective in accommodating asylum claims in their territories (Higgins, 20I7; Song, 2018; Wolman, 2015).

Considering its position in the chain of refugee flows in the region, Indonesia is a potential instigator of a regional protection regime that addresses the problem of refugees and asylum seekers. Indonesia is a developing country that geographically connects the Asian region and Australia; thus the country has long been a major transit point for asylum seekers especially those who attempt to seek protection in Australia (Missbach, 2015). However, Indonesia has been using its status as a transit country to justify Indonesia's reluctance to ratify the international Refugee Convention despite its involvement in other international human rights instruments. Although this rejection seems to contradicts Indonesia's strategy of reliance towards international refugee regime, it is politically essential for Indonesia as it legitimates the attempt of government officials to avoid the burden-shifting strategies of other destination countries, notably Australia as the closest destination country (Sampson et al., 2016). In other words, there is a deep sense of distrust towards the Convention and its ability to ensure every party who ratify it can adhere to the Convention's principles.

While the refugee population in Indonesia remains relatively small compared to other developing countries that host refugees, the recent protracted refugee crisis within the country is starting to cause an alarming situation both for the government and society. Asylum seekers and refugees in Indonesia continue to live in transit with an uncertain future as the Indonesian 
government is no longer accept generous assistance from main donor countries and organizations (Suastha, 2018). Moreover, the absence of comprehensive policy worsens the accommodation for their needs.

Looking at the constitutional foundation, the 1945 Constitution of Indonesia underlines the normative obligations of the country to respect the rights of people seeking asylum in article $28 \mathrm{G}(2)$, which emphasizes the rights of individuals to be free from persecution and to obtain political asylum from another country (Riyanto, 2004, p. 79). In addition, Indonesia's ideology of Pancasila plays a crucial role in shaping Indonesia's response to refugees because it comprises five principles that embody the humanitarian ideals of Indonesian society, especially the principle of 'just and civilized humanity' (Gordyn, 20I8). While this philosophical foundation illuminates the humanitarian imperative to deliver better treatment for refugees, there has been a failure to translate this imperative into a functioning national refugee law. In fact, the Indonesian Government has relied on ad hoc administrative regulations to respond to certain refugee situations (Reza, 20I3, pp. I23-I26). Indonesia has included asylum matters in its Law No. 37 of 1999 on Foreign Relations, which legislated that the authority to grant asylum to foreigners is the President's prerogative in consultation with the advice from ministers. This law also hinted that the President would enact policy on foreign refugees by considering the recommendations from the Minister of Foreign Affairs. This stipulation was not acted upon until the announcement of the Presidential Regulation about Foreign Refugees in 2016.

This article will explore the experiences of Indonesia in providing a certain extent of protection for international refugees during regional and global refugee crises. It argues that the contested discourse and practices of protection amid continuing control of (in) security within states are the constitutive factor for shaping the state's approaches to protect refugees. To build this argument, this article comprises five parts. It begins by discussing the conceptual framework of politics of protection relating to states' response towards international refugee crises. The three following sections discuss Indonesia's experiences in responding to three refugee crises in different time frames. The last section serves as an analytical conclusion that elaborates on the patterns on discourse and practices of refugee protection in Indonesia which accentuate states' control in defining who deserves protection, who should act to protect, and how to deliver the extent of protection. It illuminates the challenges to shape a more humane approach towards the plight of refugees as long as states' authority in modulating the security domain cannot be contested by other actors voicing for a different approach of protection.

\section{THE POLITICS OF PROTECTION IN RESPONDING REFUGEE CRISIS}

Understanding the behavior of states in the international refugee system remains relevant, especially given the ongoing tensions between the humanitarian imperatives of the international refugee regime and national interests. Scholars have investigated how states decide to execute humanitarian strategies and are willing to cooperate with other states to provide protection for refugees despite their self-interest (Betts, 20II; Snyder, 2oIo; Suhrke, I998). Suhrke (I998) argues that the tendency to use unilateral measures and the resistance to address the root causes of human displacement undermines the possibility of advancing collective actions. Other scholars have examined the normative grounds of states' responses to refugees to suggest a more ethical approach in dealing with asylum seekers and refugees (Gibney, 2004; Hathaway, I99I). While the political will of states to deliver cooperative responses are required to generate political solutions to address the protracted refugee situation, it is difficult to precisely reconcile the international responsibility to protect refugees with the domestic interest.

While refugees' rights to emigrate in order to seek asylum are internationally guaranteed and morally legitimated, the determination of providing asylum (thus opening borders to 
refugees) remains exclusively within a states' domain (Haddad, 2008, p. 87). However, the social and political dynamics within states that shape certain national responses and foreign policies to respond to refugees remain underexplored. Therefore, it is important to dismantle domestic dynamics that drive states' behaviors towards refugees to understand states' strategy in responding refugee crisis.

Huysman (2006a) discusses the politics of protection by conceptualizing 'politics of insecurity' to reconsider the relations between states as traditional provider of protection and the subjects of protection. Using the case study of asylum policy in the European Union (EU), he demonstrates that securitization can be conceptualized through three elements: domain of insecurity, security rationality and security practices as a technique of government. The basic argument underpinned these elements is that the security practices to manage unease within political communities can produce some field of insecurities (Bigo, 2002; Huysmans, 2006b, p. 4). Therefore, the insecurity framing is a political choice rather than a response to given realities, which reveals the political nature of security practices. Accordingly, security rationality is socially and politically invested in the policy area in which the meanings of security are defined and contested. Furthermore, security rationality also defines 'the logic of security practice, of how security practice modulates objects of government, integrates fragmented events and developments, and introduces specific technologies for governing freedom' (Huysmans, 2006b, p. I47). He contributes to the development of securitization theory as he argues that the construction of security questions is not limited to the use of language to explicitly define threats under exceptional conditions, but also considers language and policy as discursive practices that reflect the politics of governing. The classic securitization theory as proposed by Copenhagen School (Buzan et al., I998) seems to be inadequate to analyze security practices that do not necessarily involve discursive acts of existential threats as it relies heavily on speech acts of the prominent leaders.
According to Huysmans (2006b, p. I50), 'domains of insecurity' refers to a multidimensional process that involves linguistic, technological and institutional practices to frame certain issues as security. This concept is important for examining the securitizing move on certain issues that are not directly and specifically articulated in terms of threat definition and of the logic of exception. Based on Huysmans' experience of analyzing securitization of migration in the European Union, there are certain institutional and historical contexts in the process of securitization that make a reliance on security language and speech acts seem inadequate to understand the complexity of security framings. Therefore, in these domains, threat is subsumed by broader social and political processes that involve institutional routines and competition among political and security actors.

Further, Huysmans (2006b, p. 4I) argues that security can be understood as a technique of government to govern and control the political community. The decision to establish certain techniques is a result of contestation among actors' interests and institutional history in offering alternative framings of security questions. This contestation is what can be perceived as the politics of insecurity (Huysmans, 2006b, p. 2I). Therefore, Huysmans' concepts of the politics of insecurity is a useful starting point to investigate political discourse, institutional practices and government techniques of security to unpack the process of rendering refugees and protection issues as part of security questions (Huysmans, 2006b, p. 4).

Moreover, Huysmans utilizes this understanding about the politics of insecurity to expand his conceptual work into a 'politics of protection' approach. Specifically, this approach complements the three concepts of insecurity mentioned above with situated political agency analysis to better capture the contestation of protection. The focus on political agency corresponds with the understanding that securing practices creates insecurity, thus the role of representation is crucial in the process of socially and politically constructing insecurity (Huysmans, 2006a, p. 5). In other words, claims 
of insecurity expand the contestation of security meanings and questions of legitimacy to gain protection (who can claim for protection) of actors to provide protection (who should be responsible for protecting) and of the modality to give protection (how to do the protection) ( Huysmans, 2006a, p. 2). Furthermore, the understanding on Indonesia's domestic dynamics of protecting refugees epitomizes the position of transit country in the politics of global refugee protection. The global cooperation problem in the international refugee regime is rooted in the different interests of states as a consequence of asymmetrical power relations between Northern countries as providers of protection for refugees and Southern countries as refugee-producing countries (Betts, 20II).

However, transit countries like Indonesia do not necessarily sits well within the dichotomy of developed countries in the Global North and refugee-hosting countries in the Global South. This is because Betts' analysis hinges on the understanding that the refugee problems remain located in the southern region and the Northern states remain distant from the obligation to handle refugees in their territories. It does not provide an analytical insight if the Northern state is located within the regional source of refugee problem and thus become a preferred destination country like Australia. In the context of building cooperation to handle refugees, countries nearby the destination countries will be transit points and they have more bargaining power to prompt the Northern state to cooperate.

\section{INDONESIA AND GLOBAL REFUGEE REGIME: THE CASE OF INDOCHI- NESE REFUGEES}

Indonesia has ever contributed to the function of international refugee regime. Indonesia's responses towards the mass displacement from Indochinese countries in the aftermath of the Vietnam War has been remembered as Indonesia's humanitarian achievement (Swastiwi, 20I2). This is because of Indonesia's commitment to provide temporary protection for the Indochinese refugees who began arriving in 1975. The most appreciated contribution of Indonesia to the international refugee regime at that time was its offer to establish Galang Island as a first-asylum refugee camp to process the refugee status of people fleeing persecution and seeking international protection. This camp, operated from I979 to I996, fell under the scheme of the Comprehensive Plan of Action (CPA), initially providing temporary shelter for 50,000 Indochinese refugees seeking asylum (Betts, 2006; Jacqueline, I988, p. 48).

However, Indonesia's motives and practices for accepting the refugees during that period were based on political considerations rather than humanitarian concerns, driven by dominant state security rationales and practices to govern refugees. Instead of establishing the legal grounds for recognizing the rights of refugees to claim protection, the primary purpose of Suharto's Presidential Decision was to administratively regulate the process of temporary protection (Reza, 2013, p. I25). This regulation permitted refugees to land on Indonesia's territory, but Indonesia was hesitant to commit to a permanent protection mechanism in the form of granting asylum.

During the meeting of the Association of Southeast Asian Nations foreign ministers, the Indonesian Government circulated a position paper (Department of Foreign Affairs, I979) that became the official international statement confirming Indonesia's humanitarian commitment to provide temporary protection under certain conditions. Indonesia asked for the maintenance of national sovereignty, a commitment from the international community to provide permanent resettlement and full financial coverage from the international community in the establishment of the processing center (Department of Foreign Affairs, I979, pp. 5-6). These conditions created the dependency of the Indonesian Government on the international community and humanitarian organizations to deliver protection. The Indonesian Government permitted the UNHCR, as the primary operator of the international refugee regime, to establish an office in Jakarta, conduct refugee status determination processes and handle the provision of physical and material support to 
maintain living conditions at the Galang Island camp (Jacqueline, I988; Missbach, 2015, p. 34).

The creation of a processing center reflected the combination of reluctance and tolerance (Kneebone, 20I7, p. 30) that derived from the political tensions surrounding the decision to offer shelter for refugees. Members of parliament criticized the decision to host refugees as a hasty action given 'many more severe humanitarian problems in this country must be overcome' and perceived refugees as 'illegal migrants who have money and wealth but are entering Indonesia without permission' (Tempo, I979a). Foreign Minister Mochtar Kusumaatmadja claimed that such sentiments misunderstood the idea of Galang Island as being a permanent resettlement, when it was not.

Furthermore, the Minister of Defense and Security attempted to maintain the primacy of his department by controlling the activities in the remote processing center and the flows of Indochinese refugees coming to Indonesia. Despite the diplomatic agreement to establish Galang Island, the Minister of Defense and Security formed a security operation, 'Operasi Halilintar', to secure Indonesian waters and announced that 'starting from June $\mathrm{I}^{\text {th }}$, 1979 , the Indonesian Government would not allow Vietnamese refugees to enter Indonesian territory ... because a lot of things within Indonesian society should be addressed first' (Tempo, I979b). In responding this toughening stance of military officials, Kusumaatmadja ensured that the Indonesian government would not abandon the humanitarian aspect in responding the continuing flows of Indochinese refugees (Tempo, I979c).

Further, declaring an emergency situation and adopting the language of security would have only generated domestic instability unfavorable to Suharto's authoritarian regime. This was expressly stated in the Presidential Decision: the handling of refugees should be done 'so as not to cause disruption in national stability, and not to interfere with or hinder the development agenda,' Presidential Decision I979. Against this backdrop, the government's decision to receive a large number of refugees was intended to boost Indonesia's international image as a civilized and compassionate nation, despite its authoritarian rule. Such image building was successful, as Galang Island was considered a remarkable humanity-driven policy of the Indonesian Government to support the humanitarian mission of the UNHCR to provide international protection for refugees (Missbach, 2015, p. 4I; Swastiwi, 2012). While the issue was not securitized in terms of threat definition and was mainly considered a humanitarian disaster, it was politicized for the interests of the Indonesian Government of the day.

\section{REFUGEE CRISIS IN THE MIDST OF DEMOCRATIC TRANSITION: TAMPA CRISIS}

To comprehend the dynamics of Indonesia's accommodation of refugees in Tampa case, it is important to contextualize Indonesia's insistence as a transit country within the historical context of democratization. Since the transition to democracy took place in 1998 (Bhakti, 2004), the country faces the domestic and international pressure for the domestic enforcement of human rights (Human Rights Watch, I998), while at the same time it is focused on maintaining national stability and sovereignty in the context of national upheaval in the aftermath of the Suharto regime. Consequently, an external issue like foreign asylum seekers and refugees can only receive more attention if it has a significant effect on the domestic social and political domain. This section will elaborate the ambivalence of Indonesia's refugee regime, as it gained opportunity to be developed as a more human rights-based approach in the reform era but turned out to be a more restrictive regime towards foreign refugees.

When the refugee wave from Middle East passed through Indonesia territory to enter Australia in 200I, it became the first test for Indonesia's encounter with foreign refugee situation in the reform era. 433 asylum seekers loaded in a sinking Indonesian vessel were rescued by Norwegian vessel $M V$ Tampa in Indonesian waters. The asylum seekers insisted 
on being taken to Christmas Island, the nearest external territory of the Australian migration zone. Although Indonesia did not eventually host the Tampa refugees, this incident signifies two important features in Indonesia's experience in dealing with foreign refugees. First, the incident directed the attention of both the Indonesian Government and the public to the fast-growing migrant population from Afghanistan and the Middle East coming to Indonesia since 2000 , mostly by boat. Second, it triggered political tensions between Indonesia and Australia that led to a difficult bilateral relationship over increasing levels of peoplesmuggling from Indonesia to Australia (Phillips \& Spinks, 2013)

After the fall of Suharto's regime in I998, Indonesia was in a transitional phase of democracy that was filled with domestic turbulence. In light of the political instability, the Indonesian Government was busy handling the resettlement of Indonesians in East Timor who chose to join Indonesia as well as the IDPs as residual problems from violent conflicts in Aceh, Maluku and Kalimantan (Krustiyati, 20ıo, pp. I7-20). This internal displacement problem explains the firm rejection by the Minister of Justice at that time, Yusril Ihza Mahendra, of Australia's proposal to fund a new processing center in Indonesia's territory, emphasizing that Indonesia 'already [has] a lot of problems in this country' (Mares, 200I, p. 239). The reluctance to cooperate with Australia was a repercussion from earlier political tensions between Australia and Indonesia resulting from Australia's intervention in the East Timor conflict. It was exacerbated when the Australian Prime Minister, John Howard, urged the Indonesian Government to accept the Tampa asylum seekers and suggested Tampa was a problem to be resolved between Norway and Indonesia (PM Archive, 200Ia). As a result of this burden-shifting gesture, President Megawati halted significant bilateral cooperation with Australia in tackling the people-smuggling issue and avoided any direct communication with the Australian Prime Minister (Mares, 200I, p. 239; “Tak Ada Pintu Legal," 200I)
The view of refugees as the domestic extraburden and the political sentiments towards Australia had affected the general perception and reception of the Indonesian Government towards refugees. The government's public statements in the media portrayed the arrival of Middle-Eastern asylum seekers in Indonesia as part of irregular migration instead of considering them refugees (Lee, 2015, p. 35; Missbach, 2015, pp. 43-44). This perception was justified by the designation of the Department of Immigration, under the Ministry of Justice and Human Rights, as the leading agency in handling the management of refugees. In 2002, the Department of Immigration issued the Circular Letter on the Treatment of Foreigners who declare themselves as Asylum Seekers or Refugees (Reza, 2013, pp. I25-I26). This letter mentioned that Indonesia 'rejects aliens [orang asing] who come into Indonesia's territory and do not meet the requirements in accordance with existing regulations' (Director General of Immigration, 2002). While the letter further stated that aliens would not be deported if they declared their desire to seek asylum in Indonesia, the mindset of illegality in terms of refugees was embedded in the document, noting that such rhetoric did not appear in the Presidential Decision during the Indochinese refugee crisis. The framing of illegality derogates the status of refugees who have the right to claim protection regardless of their mode of arrival and further legitimates the use of immigration detention centers to contain asylum seekers. This migration-security approach was institutionalized through the National Police special taskforce on anti-people-smuggling in 2009 and formalized through the national Law on Immigration No. 6/20II, accentuating the negative portrayal of refugees seeking asylum in the official discourse (Missbach, 2015, p. 232; Zayzda, 20I7, p. 48).

Despite the dominant role of the immigration authorities, the Minister of Foreign Affairs, Hassan Wirajuda, was in charge of conducting foreign policies that extended Indonesia's national stance towards the mass influx of transit asylum seekers during 2000-2002. In a similar tone to the domestic interpretation of asylum 
seekers as illegal entrants, Wirajuda emphasized the urgency of international cooperation to address people-smuggling and illegal migration to dismiss Australia's urge for a bilateral deal (PM Archive, 200Ib). In the aftermath of the September II tragedy in the USA, the fear of terrorism became a legitimate security rationale to advance the international cooperation that aimed to strengthen Indonesia's border control regime. In 2002, Indonesia agreed to chair the multilateral forum, 'The Bali Process on People Smuggling, Trafficking in Persons and Related Transnational Crime' together with Australia. The co-ministerial statement of this forum mentioned that the agreement to combat illegal migration was not intended to prejudice the legitimate rights of genuine refugees to seek and enjoy asylum' but to ensure that 'protection is provided... while preventing abuse by people smugglers' (Co-Chair The Ministerial Regional Conference, 2002). Here, the security framings were at play, embedding the language of protection for victims of people-smuggling activities in the border protection framework. A year later, Wirajuda (2003) said that 'we are happy to note that the number of ... irregular migration ... has declined steadily ... In 2002 alone ... 298 Afghani irregular migrants to Indonesia chose voluntary return.'

However, this satisfaction ignores the fact that the choices of Afghani asylum seekers may not have been based on their own willingness or the provision of security in their origin country. Missbach (2015, p. 134) finds that the pressure for asylum seekers to accept voluntary repatriation instead of applying for protection to the UNHCR often came from International Organization for Migration (IOM) officers. Since the Bali Process, the IOM, with financial support from Australia, enhanced its involvement with the Indonesian Government and assisted Indonesia in designing a stronger border protection regime. The activities ranged from the advancement of capacity and skills for the Immigration Department, police, local governments and armies, to the engagement of local communities through public information campaigns to prevent locals from helping illegal migrants (Missbach, 2015, pp. I34-I43).
These practices of securing the country overshadow the mandate and works of the UNHCR to protect refugees. In the Bali Process forum, the UNHCR (2003) attempted to interfere with the logic of securitizing irregular migration; 'this is about not rejecting persons who flee to your countries but treating them properly ... fighting crime ... is not sufficient to increase border control and attack criminal networks. However, since the main mandate of the UNHCR was focused on refugee protection in terms of ensuring their well-being and finding long-term solutions, limited attempts were made and there were few resources to challenge the discourse of illegal migration disseminated by the IOM. This explains why the media coverage during this period tended to uncritically accept the negative portrayals of refugees in the security framework (Lee, 2015), despite the rising movement of human rights enforcement in the country.

\section{ROHINGYA CRISIS: ENTRANCE TO THE ESTABLISHMENT OF NEW NA- TIONAL REFUGEE REGIME?}

While the government had not adequately addressed the problem of Middle-Eastern arrivals, the Indonesian Government had to deal with another refugee crisis within the Southeast Asian region. As residual problems from Myanmar's domestic conflict, since 2009 there have been increasing waves of Rohingya refugees seeking refuge in Indonesia's territory (Rachmah et al., 20I6). No significant actions were taken by Indonesian officials until the 2015 Andaman Crisis. Almost 8,ooo Rohingya refugees from Bangladesh and Myanmar in broken vessels bobbed at sea during the "humanitarian ping-pong' among Southeast Asian countries that rejected their right to disembark on their territory (Belford \& Munawir, 2015; The Jakarta Post, 20I5).

The Rohingya crisis reveals fragmented views among government officials about the appropriate response. As an initial response to the crisis, Indonesia's military chief, General Moeldoko, articulated the refusal of the Indonesian Government to accept Rohingya refugees, 
stating that if they have difficulties at sea ... water or food, we will help because it is related to human [rights], but if they enter our territory, then the duty of the TNI [Indonesian National Armed Forces] is to maintain sovereignty' (Kompas.com, 2015). However, this statement was rebutted by Vice President Jusuf Kalla, who stated that the TNI should not reject the arrival of the refugees because 'this great nation cannot refuse to help persons in difficult situation' and 'in accordance with the second principle of Pancasila [the just and civilized humanity],... Indonesia is obliged to provide humanitarian assistance' (Kompas.com, n.d.). This receptive attitude was also driven by the success of Indonesia's Foreign Minister, Retno Marsudi, in conducting negotiation with neighboring countries, especially Malaysia and Thailand. In the emergency ministerial meeting between the three countries, Marsudi specifically negotiated for a coordinated response to accommodate 7,00o Rohingya refugees that were still stranded at sea (Gatra, 2015). The negotiation resulted in a joint statement between Indonesia and Malaysia to provide humanitarian assistance and temporary shelters for the stranded refugees 'provided that the resettlement and repatriation process will be done in one year by the international community' (Joint Statement, 2015).

This political agreement was urgent and crucial in light of growing domestic resistance from security agencies, as it provides security rationale for Indonesia to protect the lives of Rohingya refugees while ensuring the security problem caused by the refugee arrivals was handled together as an international problem. Nevertheless, the local Aceh officials maintained their strict procedures by towing stranded boats carrying Rohingya refugees (Marszal, 20I6). In a similar vein, the Minister of Justice and Human Rights, Yasonna Laoly, reiterated the urgent need for strict immigration rules and border control because of the increasing numbers of transit migrants that were causing a troubling situation and raising concerns from local government officers, while at the same time the government was struggling to take care of its citizens (VIVAnews, 20I6). Following the growing crisis in 2017 and the difficulties to sustain the provision of temporary protection in Indonesia's territory, Marsudi sought an alternative approach through a more proactive engagement with Myanmar and Bangladesh government. She conducted an intensive humanitarian diplomacy by delivering humanitarian aid to refugee camps in both countries and endorsing the UN Recommendation about 'repatriation and humanitarian assistance', 'reconstruction and rehabilitation', as well as 'development and durable peace' to prevent the continuance of humanitarian crisis in the region (Ministry of Foreign Affairs of the Republic of Indonesia, 2017; The Jakarta Post, 2017).

Different dynamics in the contestation of protection are presented through the burgeoning activities of local communities' civil society organizations in responding to the refugee crisis. In the case of the Rohingya refugees, there were stories of generous welcome towards Rohingya people by the local Acehnese and heroic actions of Aceh fishermen in rescuing distressed Rohingya refugees at sea (Suryono 20I8; Varagur 20I8). Some civil society groups and non-governmental organizations organized social events to gather donations and promote social awareness of asylum seekers and refugee issues. They also arranged political activities in the form of petitions, campaigns and demonstrations urging the Indonesian Government to deliver assistance and necessary diplomatic measures to end the humanitarian disasters and violent conflict in Myanmar. From her field observations, Missbach (2017) finds that Muslim solidarity and the pay-it-forward concept ('returning the favors', as the Acehnese received generous help during the 2004 Tsunami and separatist conflict) are the drivers for the generosity of the Acehnese people. This motivation did not appear during Indonesia's encounter with refugees from Afghanistan and the Middle East, despite similar religion ties. The important question is whether increasing public participation in supporting refugees serves as a substantial input to the development of Indonesia's refugee policy. Given the contextspecific activities and the absence of evidence of their direct involvement in the decision-making 
process, their policy contribution remains unclear. Nevertheless, the coordinated practices of local activism remain substantial as the first kind of public involvement in the history of forced migration in Indonesia (Pudjiastuti, 2016). Furthermore, the Indonesian government released a Presidential Regulation I25/2016 concerning the handling of foreign refugees. After a long delay after its first drafting in 20 Io caused by a stalemate in negotiations among ministries ("Indonesia Slams American Jerusalem Plan," 20I7; Missbach et al., 20I8), this regulation closes the legislative gaps in Indonesia's refugee policy and places the handling of refugees under the coordination of Coordinating Minister for Political, Legal and Security. This decree has been both praised and criticized. Some scholars and activists (SUAKA, 20I7; Tobing, 20I8) appreciate the removal of the term 'illegal immigrants', its focus on rescue and evacuation and its mandate for the provision of refugee shelters. Notwithstanding this, Missbach et al. (20I8) find that the regulation does not address the three most challenging issues for effective refugee protection: political will, national funding allocation and alternatives to detention. Further, the regulation does not mention the relevance of ratification of the Refugee Convention for the national refugee protection regime. It implies that Indonesia still perceives the Refugee Convention as inapplicable and too burdensome, and thus perpetuates the view that "Asian states did not "own" international refugee law' (Davies 2006, 573). (Davies, 2006, p. 573)

Considering these shortcomings, it is plausible to argue that while this regulation indicates Indonesia's better approach in refugee protection, the government maintains two stances that have traditionally guided the policies and practice of protecting refugees since the Indochinese crisis. First, it objects to the political association of protecting refugees with the ratification of the Refugee Convention, as the government strongly believes that the establishment of domestic protection is justifiable within the context of the Indonesian humanitarian tradition and national laws on human rights (Gordyn, 20I8). Second, it continues its financial and practical reliance on the international community, especially the UNHCR and the IOM, to express its view that the refugee problem is an international problem that should not burden an individual state's national priorities. Both reasons are crucial for Indonesia's national stance and international position to ensure that its 'generosity' will not be exploited by wealthy developed countries that conducting burden-shifting strategies while keeping their borders closed to refugees.

\section{CONCLUSION}

By exploring these three different crises, this chapter demonstrates the dynamics of discursive practices on refugees and the protection issue in Indonesia. Indonesia has handled refugees by rationalizing the appropriate measures for the protection claims. Acceptance towards refugees has been rendered a security problem, but it was embedded in different policy frameworks depending on the social and political contexts during the arrival of different waves of refugees. In Indonesia, although each refugee crisis unfolded during different political situations and systems of governance, the dominant discourse of refugees was continuously constructed from a highly politicized state perspective through legal policies, public statements and the policy practices of leading agencies. This discourse was dominated by a traditional state security perspective, while the humanitarian language emerged only when it was of benefit to the dominant actors' interests. For instance,, the government's decision to cooperate with international organizations like the UNHCR and the IOM cannot be considered a purely humanitarian commitment to address the plight of refugees. As demonstrated by the political discourse and security practices during the Indochinese crisis, Indonesia's offer to support the international refugee regime was part of an effort to secure Indonesia's interests by avoiding bearing the problem of mass refugee arrivals alone and buttressing the humanitarian image of the ruling government. Under the specific conditions submitted as prerequisites for the establishment of Galang Island, the Indonesian Government maintained its control over the work and activities of the UNHCR. 
In addition, as the issue of refugees had not been traditionally considered part of national priorities, the sense of heightened insecurity in the public domain was situational and limited to those who were directly affected. Consequently, there was no urgency to create a comprehensive national refugee policy to regulate the handling of refugees until the government realized the alarming protracted refugee situation caused by the Australia's unilateral policy of stopping resettlement intake from Indonesia in 2014 (Prabandari \& Dinarto, 20I6).

Indonesia has handled refugees by rationalizing the appropriate measures for the protection claims. Acceptance towards refugees has been rendered a security problem, but it was embedded in different policy frameworks depending on the social and political contexts during the arrival of different waves of refugees. The Indonesian Government maintains the strategy of conditional protection, which relies on the socio-political context of a crisis situation, domestic politics and the degree of international pressure as well as commitment from other Asian states and destination countries. While the asylum seekers issue was not initially framed as a threat to Indonesia's sovereignty, growing security concerns because of the influx of refugees and the unilateral actions of neighboring states changed the security approach and practices used to modulate insecurity towards refugees. The heavy reliance on the international community, especially the UNHCR and the IOM, has become part of the institutional routine characterizing Indonesia's response to refugee problems.

This reliance serves as Indonesia's politically strategy in enunciating refugees as an international problem that should be handled by the international community and resources. Indonesia attempts to continue its reliance on international cooperation in order to ensure the issue of protecting foreign refugees remain excluded from national responsibility. While international cooperation is a more appropriate way to deal with global refugee issue, in reality states can hide its political agenda under its dependency towards international mechanism. This can lead to difficulties to encourage national commitment on refugee issues as states tend to have over-reliance towards UNHCR or other related international organizations on the field.

Furthermore, this study examined the conditions that enabled the emergence of competing discourses produced by different agencies and whether these agencies had the power and capacity to construct of a different notion of security (Huysmans, 2006a, p. 8). The focus on agency opens the possibilities for the emergence of alternative actors that may contest, or even influence, the discourse and practices of dominant political actors and policymakers. State leaders, security agencies and policymakers traditionally define protection in terms of securing the state and its national interests; they establish policies that tend to demonstrate the unwillingness of states to welcome spontaneous mass arrivals. However, the discourse of universal human rights and international refugee norms in the context of refugee protection brings more nuances in the political processes of creating policy framework and practices. The advocacy for protecting practices that centered on refugees presents an alternative protecting discourse that challenges the dominance of state perspectives in the political site of insecurity. Although it did not directly influence the decisionmaking process of refugee policy, the active participation of local communities and refugee advocates to help refugees as demonstrated during Rohingya crisis has contributed to a more nuanced security practices delivered by the Indonesian government.

In Indonesia's case, the political tensions among state agencies have contributed to the emergence of a mixed approach to protecting and controlling refugees. Recall that humanitarian language was once used by the Indonesian Foreign Minister to negotiate for international cooperation in accommodating Indochinese refugees. The proposal to hold refugees in a processing camp had to compete with the insistence of security agencies that the arrival of boat refugees be prevented. The role of the UNHCR as one of the agencies that generate different notions about whose security 
matters in the sites of protection should also be considered. While this organization is not directly involved in the policymaking process, its presence in Indonesia, its practical contribution and its articulation of the mandate to protect refugees reflect the UNHCR's struggle to enter the contested arena of protection. Further, the increasing role of civil society and public involvement in securing asylum seekers in Indonesia's territory also brings nuance to the state's politics of protection, as the government will have to accommodate the emancipatory discourse of the rising activism.

Indonesia's response to three different refugee crises over time show how indifferent the Indonesian government when it comes to accommodating the rights of refugee to seek protection. While the insecurity grows within the communities as the refugee population may become the ticking bomb (Afriansyah, 2019) domestically, it should also be noted that the refugee protection issue can be a bomb awaiting to explode and harm the international exposure of Indonesia as well as Indonesia's international relations with neighboring countries. Tensions caused by this issue bilaterally and regionally has illustrated the extent of which the inability of responding to the refugee crisis may cause significant challenges in Indonesia's future foreign relations.

\section{REFERENCES}

Afriansyah, A. (2019). Indonesia and the Global Compacts on Refugees and Migration. International Journal of Refugee Law, 30(4), 684-686. https://doi.org/Io.Io93/ijrl/eeyo66

Barcher, A. C. (1992). First Asylum in Southeast Asia: Customary Norm or Ephemeral Concept. New York University Journal of International Law and Politics, 24, I253.

Belford, A., \& Munawir, R. (2015, May I6). Migrants in "maritime ping-pong" as Asian nations turn them back. Reuters. https://www. reuters.com/article/us-asia-migrants-idUSKBNoOio5H2O150516

Betts, A. (2006). Comprehensive Plans of Action: Insights from CIREFCA and the Indochinese CPA (Working Paper No. I20; New Issues in Refugees Research). United Nations High Commissioner for Refugees. https://www.
unhcr.org/research/working/43eb6aI52/ comprehensive-plans-action-insights-cirefcaindochinese-cpa-alexander-betts.html

Betts, A. (20II). International Cooperation in the Refugee Regime. In A. Betts \& G. Loescher (Eds.), Refugees in International Relations. Oxford University Press.

Bhakti, I. N. (2004). The Transition To Democracy In Indonesia: Some Outstanding Problems. In J. Rolfe (Ed.), The Asia-Pacific: A Region in Transition (pp. 195-206). Asia-Pacific Center for Security Studies.

Bigo, D. (2002). Security and Immigration: Toward a Critique of the Governmentality of Unease: Alternatives. https://doi. org/Io.II77/03043754020270Sio5

Buzan, B., Wæver, O., \& Wilde, J. de. (I998). Security: A New Framework for Analysis. Lynne Rienner Publishers.

Chantavanich, S., \& Reynolds, E. B. (Eds.). (I988). Indochinese refugees: Asylum and resettlement. Institute of Asian Studies, Chulalongkorn University.

Co-Chair The Ministerial Regional Conference. (2002). Bali Ministerial Conference on People Smuggling, Trafficking in Persons and Related Transnational Crime: Co-Chairs' Statement. Bali Ministerial Conference. https://www. baliprocess.net/UserFiles/baliprocess/File/ BRMCI.pdf

Davies, S. E. (2006). The Asian Rejection?: International Refugee Law in Asia**. Australian Journal of Politics \& History, 52(4), 562-575. https://doi. org/Io.IIII/j.I467-8497.2006.00433a.x

Department of Foreign Affairs. (I979). Meeting on the Establishment of a Processing Centre for Indo-China refugees. Department of Foreign Affairs of the Republic of Indonesia.

Director General of Immigration. (2002). Circular Letter of Director General of Immigration No. F-IL.OI.IO-I297 OF 2002 on the Treatment of Foreigners who declare themselves as Asylum Seekers or Refugee. Director General of Immigration, Ministry of Law and Human Rights, Republic of Indonesia.

Gatra. (2015, June 3). Rohingnya Terapung, Indonesia Menampung. Gatra, 30/XXI.

Gibney, M. J. (2004). The Ethics and Politics of Asylum: Liberal Democracy and the Response to Refugees. Cambridge University Press.

Gordyn, C. (2018). Pancasila and Pragmatism: Protection or Pencitraan for Refugees in Indonesia? Journal of Southeast Asian Human Rights, 2(2),336-357. https://doi.org/I0.19184/ jseahr.v2i2.84I4 
Haddad, E. (2008). The Refugee in International Society: Between Sovereigns. Cambridge University Press.

Hathaway, J. C. (I99I). Reconceiving Refugee Law as Human Rights Protection. Journal of Refugee Studies, 4(2), II3-I3I. https://doi.org/I0.I093/ jrs/4.2.II3

Higgins, C. (2017). Asylum by boat: Origins of Australia's refugee policy. NSW NewSouth Publishing.

Human Rights Watch. (I998, September 4). Indonesia: Soeharto-Era Abuses Must Go. Human Rights Watch. https://www.hrw. org/news/I998/o9/o4/indonesia-soehartoera-abuses-must-go

Huysmans, J. (2006a). Agency and the politics of protection: Implications for security studies. In J. Huysmans, A. Dobson, \& R. Prokhovnik (Eds.), The Politics of Protection: Sites of Insecurity and Political Agency (pp. I-I8). Routledge. http:www.routledge. com/books/The-Politics-of-Protectionisbn97804153568I7

Huysmans, J. (2006b). The Politics of Insecurity: Fear, Migration and Asylum in the EU. Routledge. http://www.routledge.com/books/ThePolitics-of-Insecurity-isbn97804I536I255

Indonesia Slams American Jerusalem Plan. (2017, December 7). VOA. https://www.voanews. com/a/indonesia-slams-american-jerusalemplan/4153226.html

Jacqueline, D. (I988). Indonesia and the Indochinese Refugees. In E. Bruce. Reynolds \& Suphāng Čhanthawānit. (Eds.), Indochinese refugees: Asylum and resettlement (pp. 48-69). Institute of Asian Studies, Chulalongkorn University. https://catalog.hathitrust.org/ Record/ooio83069

Joint Statement. (2015, May 20). Joint statement: Ministerial meeting on irregular movement of people in Southeast Asia - Myanmar. ReliefWeb. https://reliefweb.int/report/myanmar/ joint-statement-ministerial-meeting-irregular-movement-people-southeast-asia

Kneebone, S. (20I7). Australia as a Powerbroker on Refugee Protection in Southeast Asia: The Relationship with Indonesia. Refuge: Canada's Journal on Refugees, 33(I), 29-4I.

Kompas.com. (n.d.). Wapres: TNI Tidak Boleh Lagi Tolak Pengungsi Rohingya. KOMPAS. com. https://nasional.kompas.com/

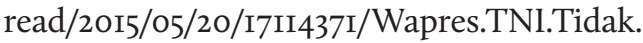
Boleh.Lagi.Tolak.Pengungsi.Rohingya.
Kompas.com. (20I5, May I5). Panglima TNI Tolak Kapal Pengungsi Rohingya Masuk RI, tapi Bersedia Beri Bantuan. KOMPAS.com. https://nasional. kompas.com/read/2015/05/15/2021330I/Panglima.TNI.Tolak.Kapal.Pengungsi.Rohingya. Masuk.RI.tapi.Bersedia.Beri.Bantuan.

Krustiyati, A. (2010). Penanganan Pengungsi di Indonesia: Tinjauan Aspek Hukum Internasional \& Nasional (Cet. I). Brilian Internasional.

Lee, A. (2015). Securitization of Transit Forced Migrants: An Analysis of the Changing Representations of Refugees and Asylum Seekers in Indonesian Major Print Media [Master Thesis, Lund University]. http://lup.lub.lu.se/ student-papers/record/5469558

Mares, P. (200I). Borderline: Australia's Treatment of Refugees and Asylum Seekers. University of New South Wales Press.

Marszal, A. (2016, June I7). Indonesian province prepares to tow stranded migrant boat back out to sea. The Telegraph. https:// www.telegraph.co.uk/news/20i6/o6/I7/ indonesian-province-prepares-to-towstranded-migrant-boat-back-o/

Ministry of Foreign Affairs of the Republic of Indonesia. (2017, October 26). "Press Briefing Menlu Retno: Capaian Tiga Tahun Politik Luar Negeri Indonesia Dalam Pemerintahan Jokowi-JK”,. https://www.kemlu.go.id/id/berita/Pages/ Menlu-Retno-Marsudi,-Capaian-Tiga-TahunPolitik-Luar-Negeri--Indonesia-DalamPemerintahan--Jokowi-JK.aspx

Missbach, A. (2015). Troubled Transit: Asylum Seekers Stuck in Indonesia. ISEAS-Yusof Ishak Institute.

Missbach, A. (20I7). Facets of Hospitality: Rohingya Refugees' Temporary Stay in Aceh. Indonesia, I04, 4I-64. JSTOR.

Missbach, A., Adiputera, Y., Prabandari, A., Cintika, G., Swastika, F. Y., \& Darningtyas, R. (20I8). Stalemate: Refugees in Indonesia - Presidential Regulation No I25 of 2016 (Policy Paper No. I4). Centre for Indonesian Law, Islam, and Society.https://law.unimelb.edu.au/centres/cilis/ research/publications/cilis-policy-papers/ stalemate-refugees-in-indonesia-presidential-regulation-no-I25-of-20I6

Moretti, S. (2018). Keeping Up Appearances: State sovereignty and the protection of refugees in Southeast Asia. European Journal of East Asian Studies, I7(I), 3-30. https://doi. org/Io.II63/157006I5-0I70I00I 
Phillips, J., \& Spinks, H. (2013). Boat arrivals in Australia since 1976 (Social Policy Section) [Research paper]. Parliamentary Library. https://www. aph.gov.au/about_parliament/parliamentary_departments/parliamentary_library/ pubs/rp/rpi3i4/boatarrivals

PM Archive. (20ora, August 27). Federal Government turns back asylum seeker. ABC Local Radio. http://www.abc.net.au/pm/stories/s427972. htm

PM Archive. (200Ib, November 28). Australia, Indonesia relations begin to thaw. ABC Local Radio. http://www.abc.net.au/pm/stories/ s427972.htm

Prabandari, A., \& Dinarto, D. (2016, August II). The Connecting Issue of Asylum Seekers and Irregular Migrants in Southeast Asia. E-International Relations. https://www.e-ir. info/2016/08/II/the-connecting-issue-of-asylum-seekers-and-irregular-migrants-in-southeast-asia/

Pudjiastuti, T. N. (2016, March I5). Bagaimana Indonesia menangani migrasi paksa. Inside Indonesia. https://www.insideindonesia.org/ bagaimana-indonesia-menangani-migrasipaksa

Rachmah, R. A., Pestalozzi, Z. E., \& Andarmosoko, I. (20I6). Barely Living: Research on Living Conditions of Rohingya Refugees in Indonesia (First edition). Lembaga Bantuan Hukum Jakarta.

Reza, B. I. (2013). Challenges and Opportunities in Respecting International Refugee Law in Indonesia. In A. Francis \& R. Maguire (Eds.), Protection of Refugees and Displaced Persons in the Asia Pacific Region, ed. Angus Francis and Rowena Maguire (: , 20I3) (pp. II7-34). Ashgate Publishing Company.

Riyanto, S. (2004). Urgensi Legislasi Hukum Pengungsi dan Kendalanya di Indonesia. Indonesian Journal of International Law, 2, 67.

Sampson, R. C., Gifford, S. M., \& Taylor, S. (20I6). The myth of transit: The making of a life by asylum seekers and refugees in Indonesia. Journal of Ethnic and Migration Studies, 42(7), II35-II52. https://doi.org/Io.I080/I369I8 3X.20I5.11306II

Snyder, J. (20I0). Realism, Refugees, and Strategies of Humanitarianism. In A. Betts \& G. Loescher (Eds.), Refugees in International Relations (pp. 85-I04). Oxford University Press.

Song, L. (2018). China and the International Refugee Protection Regime: Past, Present, and Potentials. Refugee Survey Quarterly, 37(2), I39-I6r. https://doi.org/Io.Io93/rsq/hdyoo3
SUAKA. (20I7, January I8). Press Release SUAKA: Perpres RI no.125/2016 tentang Penanganan Pengungsi Dari Luar Negeri. Suaka. https:// suaka.or.id/20I7/or/i8/press-release-suakaperpres-ri-no-I2520I6-tentang-penanganan-pengungsi-dari-luar-negeri/

Suastha, R. D. (2018). IOM Setop Dana Bantuan Bagi Pengungsi Baru di Indonesia. CNN Indonesia. https://www.cnnindonesia.com/ internasional/20180506092728-106-296043/ iom-setop-dana-bantuan-bagi-pengungsibaru-di-indonesia

Suhrke, A. (I998). Burden-sharing during Refugee Emergencies: The Logic of Collective versus National Action. Journal of Refugee Studies, II(4), 396-4I5. https://doi.org/Io.Io93/ jrs/II.4.396

Swastiwi, A. W. (2012). Pulau Galang, wajah humanisme Indonesia: Penanganan manusia perahu Vietnam, 1978-1996 (A. W. Adam, Ed.; Cetakan I). Kementerian Pendidikan dan Kebudayaan, Direktorat Jenderal Kebudayaan, Direktorat Sejarah dan Nilai Budaya.

Tak Ada Pintu Legal. (20oI, November 3). Majalah Gatra, October 50/VII. http://majalah. gatra.com/200I-Io-30/majalah/artikel. php?id=41607

Tempo. (I979a, March 3I). Kita Bukan Tukang Tampung. Majalah Tempo. https://majalah. tempo.co/read/nasional/54347/kita-bukantukang-tampung

Tempo. (I979b, June 23). "Cahaya” Jangan Datang di Laut. Majalah Tempo. https://majalah.tempo. co/read/nasional/54774/cahaya-jangandatang-di-laut

Tempo. (I979c, June 23). Mungkin Sedang Terjadi Sesuatu ... Tempo Interview with the Foreign Minister Mochtar Kusumaatmaja. Majalah Tempo. https://majalah.tempo.co/read/nasional/54776/mungkin-sedang-terjadi-sesuatu

The Jakarta Post. (2015, May 15). More than 800 land in Indonesia, Thailand in growing crisis. The Jakarta Post. https://www.thejakartapost. com/news/2015/05/15/more-8oo-land-indonesia-thailand-growing-crisis.html

The Jakarta Post. (20I7, January 2). Indonesia carries out intensive diplomacy on Rohingya: Minister. The Jakarta Post. https://www.thejakartapost. com/news/20I7/or/o2/indonesia-carries-outintensive-diplomacy-on-rohingya-minister. html

Tobing, D. H. (2018, January I2). A year of Jokowi's refugee decree: What has changed? The Jakarta Post. https://www.thejakartapost.com/ academia/20I8/oI/I2/a-year-of-jokowisrefugee-decree-what-has-changed.html 
UNHCR. (2003). Regional Ministerial Conference on People Smuggling, Trafficking in Persons and Related Transnational Crime (Bali II). https://www.baliprocess.net/UserFiles/ baliprocess/File/Statement\%2oby\%2othe\%20 UNHCR\%20to\%2oBali\%2oll.pdf

VIVAnews. (2016, August 9). Menkumham: Indonesia Kewalahan Hadapi Imigran. viva.co.id. https:// www.viva.co.id/berita/nasional/806964menkumham--indonesia-kewalahan-hadapiimigran

Wirajuda, H. (2003). Statement by H. E. Dr. N. Hassan Wirajuda Minister for Foreign Affair at Preparatory Meeting for The Second Regional Ministerial Conference on People Smuggling, Trafficking in Persons and Related Transnational Crimes. The Department of Foreign Affairs of the Republic of Indonesia. https:// www.baliprocess.net/UserFiles/baliprocess/ File/Statement.pdf
Wolman, A. (2015). Japan and international refugee protection norms: Explaining non-compliance. Asian and Pacific Migration Journal, 24(4), 409-43I. https://doi. org/I0.II77/OII7I968I5606852

Zayzda, N. A. (20I7). Sekuritisasi Migrasi Paksa Pengungsi Lintas-Batas di Indonesia. Seminar Nasional Hukum Universitas Negeri Semarang, 3(I), 43-54. 
